\begin{tabular}{l} 
Available online at: http://journal.uny.ac.id/index.php/ljtp \\
LingTera, 5 (2), 2018, 179-188 \\
\hline
\end{tabular}

\title{
Pengembangan perangkat menulis teks eksposisi berdasarkan pendekatan pembelajaran berbasis masalah bagi siswa sekolah menengah pertama
}

\author{
Cipto Cipto \\ SMP Negeri 2 Jawai Selatan. Jalan Pantai Utara, RT/RW 1/1, Bukit Raya, Jawai Laut, Jawai Selatan, \\ Kabupaten Sambas, Kalimantan Barat, Indonesia \\ * Coresponding Author. E-mail: angah.cipto@yahoo.co.id \\ Received: 12 November 2015; Revision: 20 August 2018; Accepted: 25 December 2018
}

\begin{abstract}
Abstrak
Penelitian ini bertujuan untuk menghasilkan perangkat pembelajaran menulis teks eksposisi berdasarkan pendekatan PBM bagi siswa SMP yang layak, praktis, dan efektif. Penelitian pengembangan ini mengacu pada langkah yang dikembangkan oleh Borg and Gall. Desain pengembangan dikelompokkan dalam lima tahap prosedur pengembangan yang meliputi: studi pendahuluan, desain produk, validasi produk, uji coba terbatas dan luas, dan produk akhir. Subjek uji coba terbatas terdiri atas 10 siswa kelas VII SMPN 1 Jawai, sedangkan subjek uji coba luas terdiri atas 20 siswa kelas VII SMPN 2 Jawai Selatan Kabupaten Sambas. Instrumen pengumpulan data yang digunakan adalah lembar validasi untuk ahli materi dan ahli pembelajaran, lembar keterlaksanaan pembelajaran, lembar respon siswa, angket penilaian guru, dan instrumen evaluasi pembelajaran. Penelitian ini menghasilkan perangkat pembelajaran menulis teks eksposisi meliputi: silabus, RPP, buku ajar siswa (BAS), dan instrumen evaluasi pembelajaran (IEP) masuk dalam kategori "baik"; perangkat yang dikembangkan untuk aspek keterlaksanaan pembelajaran, aspek penilaian guru, dan lembar respon siswa dinyatakan praktis dengan seluruh lembar penilaian masuk dalam kategori "baik"; dan dinilai efektif dalam meningkatkan hasil belajar aspek sikap, aspek pengetahuan, dan aspek keterampilan. Hasil penelitian menunjukkan perangkat pembelajaran berdasarkan pendekatan PBM layak, praktis, dan praktis digunakan sebagai salah satu sumber belajar untuk meningkatkan keterampilan siswa dalam menulis teks eksposisi.
\end{abstract}

Kata Kunci: pengembangan perangkat pembelajaran, teks eksposisi, pendekatan pembelajaran berbasis masalah, siswa SMP.

\section{Developing of writing exposition-text teaching kits based on problem based learning approach for junior high school students}

\begin{abstract}
This study aims to develop of a writing exposition-text teaching kit based on the Problem-Based Learning (PBL) Approach for junior high school students which is appropriate and valid, the feasibility, and the effectiveness. This study used the research and development model developed by Borg and Gall. It consisted of five steps consisting of: preliminary study, product design, validation, limited-test of the product design and field-test of the primary developed-product, and final products. Ten grade VII students of SMPN 1 Jawai involved in limited test, and 20 students of SMPN 2 Jawai Selatan Sambas Regency involved in the field-test of the products. The instruments used to gather the data included a set of validation sheets for the expert (pedagogical and content aspects), observation sheet of teaching-learning process, questionnaire for students' response, evaluation sheet for the teacher, and a test. The results of the study are the writing exposition-text teaching kit consists of syllabi, lesson plan, students' book and the assessment in a 'good' category; the developed teaching kit is in a 'good' category based on the students achievement in teaching learning processes, evaluation from the teacher, and students' response to the questionnaire; and teaching kit effective in improving students' achievement in cognitif aspect, students' skill in writing exposition-text. Hence, the teaching kit based on PBL approach is valid, effective and feasible as learning sources to improve students' skill in writing exposition-text.
\end{abstract}

Keywords: teaching kit, exposition text, problem-based learning approach, junior high school students.

How to Cite: Cipto, C. (2018). Pengembangan perangkat menulis teks eksposisi berdasarkan pendekatan pembelajaran berbasis masalah bagi siswa sekolah menengah pertama. LingTera, 5(2), 179-188. doi:https://doi.org/10.21831/lt.v5i2.6908

https://doi.org/10.21831/lt.v5i2.6908 


\section{PENDAHULUAN}

Menulis merupakan satu di antara keterampilan berbahasa yang berperan penting dalam pembelajaran. Peran penting keterampilan menulis tersebut sebagai wadah siswa dalam mengembangkan ide dengan menggunakan media tulis baik teks faktual maupun teks fiksi. Tarigan, (2008, p. 22) mengemukakan bahwa menulis sangat penting bagi pendidikan karena memudahkan para pelajar berpikir. Hal ini sangat wajar karena menulis merupakan keterampilan produktif representasi dari kegiatan pembelajaran yang dilakukan setelah siswa menggali pengetahuan melalui kegiatan berbahasa lain seperti keterampilan menyimak, membaca, serta berbicara.

Teks eksposisi merupakan teks yang dijadikan sumber topik bahasan dalam pembelajaran bahasa Indonesia di SMP. Pembahasan materi teks eksposisi diharapkan dapat memahami struktur teks eksposisi yang terdiri atas tesis atau opini, argumentasi-argumentasi, dan penegasan ulang. Mahsun (2014, p. 31) mengemukakan bahwa teks eksposisi berisi paparan gagasan atau usulan sesuatu yang bersifat pribadi". Itu sebabnya, teks ini sering juga disebut sebagai teks argumentasi satu sisi.

Pertimbangan dalam pemilihan teks eksposisi dalam penelitian ini berdasarkan hasil penelitian Nely (2014, p. 3) mengungkapkan bahwa kendala yang dihadapi siswa adalah merasa sulit mendapatkan inspirasi, ketidakmampuan dalam memilih kata, kalimat, dan siswa kesulitan dalam memulai menulis karangan eksposisi. Bertitik tolak dari pendapat tersebut ada dua persoalan yang tampak dalam menulis teks eksposisi yang dihadapi guru pertama, kesulitan siswa dalam mencari inspirasi ide dalam menulis teks eksposisi. Kedua, persoalan pendidik berkaitan dengan pemilihan pendekatan, strategi atau model pembelajaran belum memberikan pemahaman terhadap materi pembelajaran secara optimal.

Berdasarkan hasil observasi awal di sekolah SMP Negeri 2 Jawai Selatan didapatkan bahwa (1) guru belum memaksimalkan penggunaan perangkat seperti silabus dan rencana pelaksanaan pembelajaran, (2) guru dalam proses pembelajaran belum optimal melaksanakan pendekatan, model, metode dan strategi pembelajaran terpusat pada siswa, (3) pembelajaran yang diberikan belum mampu menghasilkan kemandirian siswa dan materi yang didapat siswa masih bersifat tekstual, tetapi belum mengembangkan materi secara kontekstual atau materi yang berkaitan dengan siswa dalam kehidupan sehari-hari.

Berdasarkan permasalahan tersebut, dibutuhkan pendekatan pembelajaran yang inovatif dengan harapan dapat memberi warna dalam pembelajaran menulis teks eksposisi di kelas. Pengembangan materi yang sesuai dengan persoalan hidup siswa (kontekstual). Pengembangan perangkat yang efektif bagi guru dan bermanfaat untuk siswa. Selain itu, pengembangan pendekatan PBM diharapkan menjadi sebuah solusi konstruktif dalam memberikan variasi pembelajaran.

Pendekatan pengajaran yang dilakukan guru dalam proses belajar mengajar di kelas mempunyai peran penting dalam meningkatkan kualitas siswa. Oleh karenanya, dengan pendekatan pengajaran yang konstruktif guna memperbaiki proses pembelajaran dan meningkatkan minat siswa dalam mengikuti keberlangsungan pembelajaran. Salah satu pendekatan pembelajaran inovatif untuk memperbaiki kualitas pembelajaran dapat digunakan pendekatan PBM.

Hal ini penting dilakukan karena salah satu kunci bagi pengajaran penyelesaian masalah adalah menyediakan masalah yang membangkitkan minat dan memikat siswa. Kemampuan penyelesaian masalah yang sama dapat dilibatkan dalam konteks yang menarik atau membosankan bagi siswa, dan hal ini berperan penting dalam hasilnya (Slavin, 2011, p. 33). Selain itu, Kementerian Pendidikan dan Kebudayaan Republik Indonesia (2014, p. 43) menyatakan bahwa pembelajaran berbasis masalah merupakan sebuah pembelajaran yang dilakukan dengan menyajikan masalah kontekstual sehingga merangsang siswa untuk belajar. Penerapan pembelajaran berbasis masalah di dalam kelas, siswa bekerja dalam tim untuk memecahkan masalah dunia nyata (real world). Permasalahan yang menarik adalah permasalahan yang bersentuhan dengan dunia nyata siswa, baik persoalan personal siswa (seperti, motivasi, bakat, nilai moral, dll) maupun persoalan sosial lainnya yang disesuaikan dengan perkembangan siswa.

Guru perlu melakukan berbagai upaya dalam hal berinovasi dalam bidang pembelajaran. Pembaharuan pembelajaran yang dilakukan baik dengan memanfaatkan pendekatan pembelajaran, pengembangan materi atau topik bahasan yang representatif dengan tujuan pembelajaran, media, metode inovatif dan penilaian yang efektif. Selain itu, perbaikan dan pengembangan penyelenggaraan pembelajaran yang berkualitas secara kontinu dengan memberikan perhatian terhadap temuan kreativitas dan inovasi proses pembel- 
ajaran oleh penyelenggara pendidikan perlu ditingkatkan.

Oleh karena itu, diperlukan pemikiran konstruktif yang dilakukan guru dengan melakukan inovasi pembelajaran terutama pembelajaran bahasa Indonesia di kelas. Inovasi-inovasi yang dapat dilakukan dengan pengembangan perangkat pembelajaran. Perangkat yang digunakan dalam pembelajaran disebut dengan perangkat pembelajaran yaitu, pengembangan silabus, rencana pelaksanaan pembelajaran, pengembangan materi (buku ajar), dan instrumen evaluasi pembelajaran (IEP).

Pengembangan perangkat yaitu silabus, RPP, BAS, dan IEP sangat penting dilakukan. Prabhu (1987, p. 86) mengemukakan bahwa silabus merupakan penerapan sebagai pernyataan tentang apa yang akan diajarkan. Rencana pelaksanaan pembelajaran adalah perencanaan pelajaran sering dipandang sebagai aspek kunci dari mengajar pelajaran sukses (Richards \& Renandya, 2002, p. 27). Daryanto \& Dwicahyono (2014, p. 97) mengemukakan bahwa materi pembelajaran (buku ajar) adalah materi yang digunakan untuk mencapai tujuan pembelajaran dan indikator. Evaluasi pembelajaran sebagai suatu proses untuk mengetahui (menguji) apakah tujuan pembelajaran sesuai suatu kegiatan, proses kegiatan, kekuatan suatu program telah sesuai dengan tujuan atau kriteria yang telah ditentukan (Nurgiyantoro, 2013, p. 6). Oleh karena itu, Pengembangan perangkat pembelajaran sangat penting dilakukan oleh guru sebagai penopang keberhasilan pembelajaran di kelas.

Pentingnya pemanfaatan perangkat pembelajaran oleh guru dengan optimal akan memberikan hasil yang maksimal. Namun, kesadaran guru dalam mengembangkan perangkat pembelajaran masih terbatas. Hal ini terjadi disebabkan oleh guru dimanjakan oleh sumber belajar yang ada dan tidak mengecek apakah sumber belajar yang diajarkan sesuai atau tidak dengan karakteristik siswa setempat. Untuk itu, dalam penelitian ini menggali pengembangan perangkat pembelajaran bahasa Indonesia teks menulis eksposisi sebagai inovasi yang perlu disoroti untuk mengetahui kualitas pembelajaran setelah pemanfaatan inovasi dibuat dan dilaksanakan.

Berdasarkan hasil analisis tersebut, pengembangan perangkat tampaknya dapat memberikan kontribusi positif terhadap inovasi dalam pengajaran mengombinasi keterampilan menulis teks eksposisi dan pendekatan pembelajaran berbasis masalah. Pertimbangan lain memilih penelitian ini disebabkan masih terbatasnya pengembangan perangkat menulis teks eksposisi berdasarkan pendekatan PBM di SMP Kabupaten Sambas. Untuk itu, penelitian ini akan menyelidiki pengembangan perangkat pembelajaran menulis teks eksposisi berdasarkan pendekatan pembelajaran berbasis masalah bagi siswa SMP yang layak, praktis, dan efektif.

Dengan demikian muncul pertanyaan, bagaimana pengembangan yang dilakukan untuk menghasilkan perangkat pembelajaran menulis teks eksposisi berdasarkan pendekatan PBM yang layak, praktis, dan efektif bagi siswa SMP. Adapun penelitian ini dilakukan dengan tujuan menghasilkan model perangkat pembelajaran menulis teks eksposisi berdasarkan pendekatan PBM yang layak, praktis, dan efektif bagi siswa SMP.

\section{METODE}

Penelitian ini merupakan penelitian pengembangan atau dikenal dengan istilah $R \& D$ (Research and Development). Pada penelitian ini yang dilakukan mengembangkan perangkat pembelajaran menulis teks eksposisi berdasarkan pendekatan pembelajaran berbasis masalah bagi siswa SMP kelas VII. Model perangkat pembelajaran yang dikembangkan meliputi silabus, rencana pelaksanaan pembelajaran, pengembangan materi (buku ajar), dan instrumen evaluasi pembelajaran.

Model pengembangan yang digunakan dalam penelitian ini diadaptasi dari rancangan pengembangan Gall, Gall, \& Borg (2007) dengan model pengembangan menjadi lima tahap yaitu: (1) studi pendahuluan, (2) desain produk, (3) validasi, (4) uji coba terbatas dan revisi produk, dan (5) produk akhir.

Prosedur pengembangan diadaptasi dari model Gall, Gall, \& Borg (2007). Dalam penelitian ini serangkaian prosedur dirancang dan dimodifikasi dengan 5 tahap adalah sebagai berikut.

\section{Studi Pendahuluan}

Kegiatan yang dilakukan dalam tahap perencanaan ini meliputi: (a) analisis kebutuhan, (b) analisis SKL, SK, KD dan spesifikasi indikator keberhasilan, (c) analisis kebutuhan siswa, (d) analisis buku ajar yang digunakan di sekolah, analisis materi/isi, dan (e) analisis berbagai variasi penugasan.

\section{Desain Produk}

Tahapan kegiatan yang dilakukan dalam desain produk adalah sebagai berikut: (a) penentuan KI-KD, (b) penetapan indikator keberhasil- 
an pembelajaran, (c) penetapan materi, (d) pemilihan model/pendekatan, (e) pemilihan dan pembuatan media, dan (f) perancangan bentuk awal perangkat pembelajaran yang dikembangkan yaitu silabus, RPP, BAS, dan IEP (draf 1).

Validasi

Tahapan yang dilakukan dalam kegiatan ini terdiri atas: (a) uji kelayakan yang dilakukan dilakukan oleh ahli materi dan ahli pembelajaran bahasa Indonesia, (b) analisis data validasi dan jika masih terdapat kriteria kelayakan yang belum terpenuhi maka perlu dilakukan revisi. Perangkat yang telah direvisi disebut produk draf 2.

\section{Uji Coba dan Revisi Produk}

Hasil yang diperoleh dari kegiatan penilaian perangkat pembelajaran dikembangkan sebagai acuan untuk melakukan revisi terhadap produk yang dibuat sebelumnya. Hasil revisi I selanjutnya digunakan untuk uji coba terbatas, setelah uji coba terbatas dilakukan revisi II terhadap perangkat pembelajaran sebelumnya. Hasil revisi II digunakan untuk uji luas dan dilakukan revisi III untuk hasil produk akhir.

Produk Akhir

Produk akhir diperoleh berdasarkan hasil dari revisi-revisi perangkat pada tahap sebelumnya. Kemudian langkah selanjutnya disusun perangkat pembelajaran menulis teks eksposisi berdasarkan pendekatan PBM bagi siswa SMP.

Adapun produk yang dihasilkan dari pengembangan ini yaitu: silabus, RPP, buku ajar siswa (BAS), dan instrumen evaluasi pembelajaran (IEP). Tabel 1 merupakan instrumen penilaian yang digunakan dalam penelitian ini.

Tabel 1. Instrumen Penilaian

\begin{tabular}{ll}
\hline \multirow{2}{*}{ Kualitas } & Instrumen yang Digunakan \\
\cline { 2 - 2 } Kelayakan & Perangkat Pembelajaran \\
& $\begin{array}{l}\text { Instrumen penilaian Silabus } \\
\text { Instrumen penilaian RPP }\end{array}$ \\
& Instrumen Penilaian Buku Ajar \\
& Siswa \\
& Instrumen IEP Aspek Pengetahuan \\
& Instrumen IEP Aspek Keterampilan \\
& Instrumen IEP Aspek Sikap \\
Kepraktisan & Lembar Keterlaksaan Pembelajaran \\
& Lembar Penilaian Guru \\
& Lembar Penilaian Siswa \\
Keefektifan & Instrumen Evaluasi Pembelajaran \\
\hline
\end{tabular}

Uji coba perangkat pembelajaran yang dihasilkan dalam pengembangan ini dilakukan pada siswa kelas VII SMP tahun ajaran 2014/
2015. Uji coba dilakukan pada tanggal 25 Mei-11 Juni 2015 Lokasi penelitian adalah SMP Negeri 1 Jawai dan SMP Negeri di Kabupaten Sambas Kalimantan Barat.

Subjek uji coba dalam penelitian ini adalah siswa kelas VII yang terdaftar tahun pelajaran 2014/2015. Uji coba terbatas melibatkan satu orang guru mitra, dua orang observer dan 10 orang siswa kelas VII SMPN 1 Jawai. Uji coba luas melibatkan satu orang guru mitra, dua orang observer dan 20 siswa kelas VII SMPN 2 Jawai Selatan Kabupaten Sambas.

Jenis data dalam penelitian ini berupa data kualitatif dan kuantitatif. Data kualitatif diperoleh pada penelitian berupa saran dan komentar dari validator. Data kuantitatif diperoleh dari skor tanggapan validator terhadap perangkat pembelajaran, skor lembar keterlaksanaan pembelajaran, skor lembar penilaian guru, skor lembar respon siswa, dan hasil tes instrumen evaluasi pembelajaran.

Analisis data dalam penelitian ini bertujuan menjawab pertanyaan penelitian. Data yang berupa komentar, saran, revisi, dan hasil observasi selama proses uji coba dianalisis secara deskriptif kualitatif dan disimpulkan sebagai masukan untuk merevisi produk yang dikembangkan. Adapun data yang berupa skor tanggapan ahli, skor penilaian guru, skor respon siswa, dan tes instrumen evaluasi pembelajaran.

Secara umum teknik analisis data dalam penelitian ini yaitu data dikelompokkan berdasarkan kualifikasi produk yang akan dinilai. Dilakukan perhitungan rata-rata atas data yang telah dikelompokkan. Dari rata yang didapatkan kemudian diubah ke dalam kriteria kualitatif dengan ketentuan seperti pada Tabel. Kriteria Tabel 2 diadaptasi dari Sukardjo (2014) untuk mengetahui kualitas produk yang dikembangkan. Kriteria konversi skor pada skala lima tersaji pada Tabel 2 .

Tabel 2. Konversi Skor pada Skala Lima

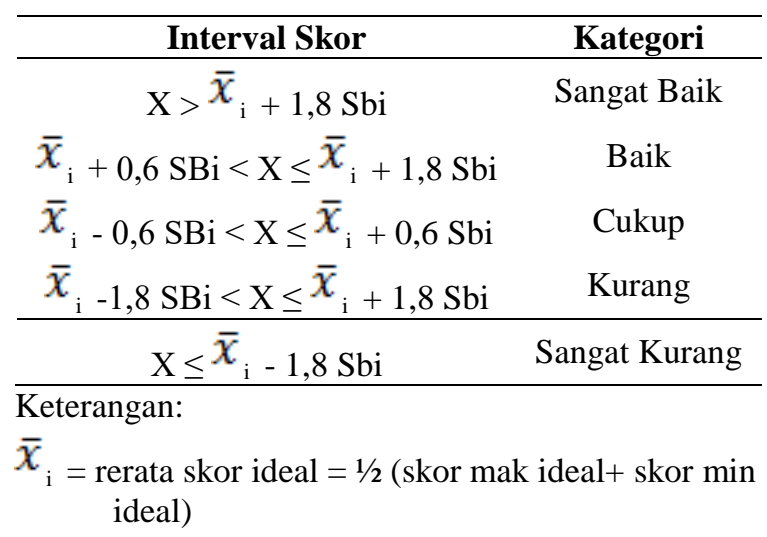


$\mathrm{SBi}=$ simpangan baku ideal $=1 / 6($ skor maks ideal + skor min ideal)

$\mathrm{X}=$ rerata ideal $=1 / 2$ (skor maks ideal + skor $\min$ ideal) atau total skor aktual.

Skor tertinggi ideal $=\sum$ butir kriteria $\mathrm{x}$ skor tertinggi Skor terendah ideal $=\sum$ butir kriteria $\mathrm{x}$ skor terendah

Penentuan kepraktisan perangkat pembelajaran dilihat dari konsistensi hasil penilaian praktisi (guru yang menggunakan produk), respon siswa dan hasil penilaian pengamat dari keterlaksanaan pembelajaran di kelas. Berdasarkan hasil penilaian guru dan respon siswa ditentukan total skor aktual, selanjutnya total skor aktual dikonsultasikan pada interval kriteria kepraktisan yang ditunjukkan Tabel 3.

Tabel 3. Interval Kriteria Kepraktisan Pembelajaran

\begin{tabular}{ccl}
\hline Interval (\%) & Nilai & \multicolumn{1}{c}{ Kategori } \\
\hline $86-100$ & A & Sangat Baik \\
$71-85$ & B & Baik \\
$56-70$ & C & Cukup \\
$41-55$ & D & Kurang \\
$\leq 40$ & E & Sangat Kurang \\
\hline
\end{tabular}

Perangkat pembelajaran dikatakan praktis jika minimal kategori kepraktisan yang dicapai baik, khususnya untuk kriteria kepraktisan berdasarkan respon siswa perangkat yang dikembangkan dikatakan praktis jika minimal baik mencapai $80 \%$.

Penentuan keefektifan perangkat menulis yang dikembangkan dilihat dari pencapaian indikator/aspek keefektifan yang ditetapkan berdasarkan analisis data uji coba luas yang terdiri atas tiga aspek, yaitu: (1) analisis instrumen evaluasi pembelajaran aspek sikap, (2) analisis instrumen evaluasi pembelajaran aspek pengetahuan, dan (3) analisis evaluasi pembelajaran aspek keterampilan. Data hasil pengukuran ketiga aspek keefektifan perangkat sebagai berikut.

Pertama, selama proses pembelajaran di kelas siswa berada di bawah pengamatan dua orang penilai lembar instrumen evaluasi pembelajaran aspek sikap. Lembar pengamatan aspek sikap siswa memiliki beberapa aspek yang dinilai berkaitan dengan sikap spritual dan sosial. Aspek sikap spritual yang dinilai berhubungan dengan menghargai dan mensyukuri keberadaan bahasa Indonesia sebagai anugerah Tuhan Yang Maha Esa sebagai sarana memahami informasi lisan dan tertulis. Sikap sosial yaitu, sikap kreatif, tanggung jawab, dan santun. Teknik yang digunakan adalah deskriptif kualitatif. Ketuntasan minimal sikap spritual dan sosial siswa minimal 2,33-3,33 (kategori $\geq B$ ).

Kedua, instrumen ini digunakan untuk memeroleh data hasil belajar siswa dalam pembelajaran dengan menggunakan perangkat pembelajaran menulis teks eksposisi dengan menggunakan pembelajaran berbasis masalah. Tes adalah instrumen evaluasi pembelajaran berbentuk tes uraian. Hasil tes instrumen pembelajaran siswa ditentukan berdasarkan penilaian acuan patokan. Skor yang diperoleh siswa melalui instrumen evaluasi pembelajaran (IEP) akan digunakan untuk menentukan ketuntasan individual dan ketuntasan klasikal siswa terhadap indikator yang ditetapkan.

Data hasil evaluasi pembelajaran dilakukan secara analisis deskriptif kuantitatif, meliputi: indeks sensitivitas merupakan penilaian melalui analisis butir soal lebih diutamakan pada analisis sensitivitas. Validitas suatu butir soal didefinisikan sebagai seberapa jauh suatu butir soal dapat memberikan efek instruksional. Indeks sensitivitas dari suatu butir soal pada dasarnya merupakan ukuran seberapa baik butir soal itu membedakan kemampuan sebelum dan sesudah pembelajaran. Suatu butir soal dikatakan peka terhadap pembelajaran apabila $S \geq 0,30$.

Ketuntasan siswa minimal 2,67 (Predikat $\geq$ B) untuk aspek pengetahuan (Ketuntasan nilai siswa di SMPN 1 Jawai dan SMPN 2 Jawai Selatan). Data hasil hasil pretest dan posttest pengetahuan teks eksposisi siswa yang asli (sebelum dikonversi) dianalisis dengan $\mathrm{N}$-gain. Penggunaan gain-score (skor peningkatan) yang menunjukkan peningkatan pengetahuan teks eksposisi siswa sebelum dan sesudah perlakuan.

Hasil evaluasi pembelajaran aspek keterampilan yang dimaksud penilaian keterampilan kinerja menangkap makna dan menyusun teks eksposisi. Data hasil evaluasi pembelajaran keterampilan diperoleh dari pengamatan kinerja selama proses pembelajaran berlangsung atau pada saat siswa mengerjakan lembar kerja siswa di bawah pengamatan guru yang mengajar.

Aspek keterampilan yang dinilai dengan teknik deskriptif kualitatif. Ketika nilai siswa minimal 2,67 (dengan predikat $\geq$ B) siswa sudah tuntas (ketuntasan nilai siswa SMPN 1 Jawai dan SMPN 2 Jawai Selatan).

\section{HASIL DAN PEMBAHASAN}

Hasil penelitian ini terdiri atas lima model perangkat pembelajaran menulis teks eksposisi berdasarkan pendekatan pembelajaran berbasis masalah bagi siswa SMP, yaitu (1) model silabus 
pembelajaran menulis teks eksposisi berdasarkan pendekatan PBM, (2) model RPP pembelajaran menulis teks eksposisi berdasarkan pendekatan PBM, (3) model buku ajar siswa pembelajaran menulis teks eksposisi berdasarkan pendekatan PBM yang dapat dilihat di http://tiny.cc/ekposisi, dan (4) model instrumen evaluasi pembelajaran berdasarkan pendekatan PBM.

Keempat model perangkat pembelajaran yang telah dikembangkan diuji ahli, uji coba terbatas, dan uji coba luas. Uji ahli dilakukan untuk mengetahui kelayakan perangkat yang dikembangkan. Adapun uji coba terbatas dan uji coba luas untuk mengetahui kepraktisan dan keefektifan perangkat pembelajaran yang dikembangkan.

\section{Hasil Uji Coba Produk}

Data uji coba dalam penelitian ini terdiri atas: (1) kelayakan data hasil validasi ahli materi dan pembelajaran bahasa Indonesia, (2) kepraktisan produk pada uji coba terbatas dan uji coba luas, dan (3) keefektifan uji coba terbatas dan uji coba luas.

\section{Kelayakan Produk}

Setelah draf awal perangkat pembelajaran menulis teks eksposisi berdasarkan pendekatan pembelajaran berbasis masalah dirancang, maka sebelum diujicobakan draf awal ini divalidasi oleh ahli materi dan pembelajaran. Validasi dilakukan untuk melihat isi dari draf awal. Validasi juga bertujuan untuk menggali komentar dan saran, baik secara tertulis maupun lisan dengan cara berdiskusi tentang perangkat pembelajaran yang dikembangkan.

Kegiatan validasi dilakukan dengan cara memberikan naskah perangkat pembelajaran (silabus, rencana pelaksanaan pembelajaran, buku ajar siswa, dan instrumen evaluasi pembelajaran) beserta lembar validasi kepada validator. Validator ahli terdiri atas ahli materi dan ahli pembelajaran bahasa Indonesia. Hasil validasi untuk masing-masing validator dapat dilihat pada Tabel 4.

Data pada Tabel 4 menunjukkan bahwa penilaian dari para ahli secara keseluruhan model perangkat yang dikembangkan dinyatakan memenuhi kriteria valid. Hasil penilaian yang diberikan oleh pakar menunjukkan bahwa silabus yang dikembangkan layak digunakan dalam pembelajaran menulis teks eksposisi di kelas. Langkah-langkah silabus yang dikembangkan meliputi: (1) identitas silabus; (2) standar kompetensi; (c) materi pelajaran; (d) kegiatan pembelajaran; (e) indikator pencapaian kompetensi; (f) penilaian; (g) alokasi waktu; dan (h) sumber belajar. Langkah-langkah yang dikembangkan merupakan gambaran sebagai pernyataan tentang apa yang akan diajarkan (Prabhu, 1987, p. 86).

Skor total penilaian kelayakan rencana pelaksanaan pembelajaran (RPP) adalah 3,51 atau rerata skor 4,18 dengan kategori "baik". Hasil penilaian yang diberikan ahli materi dan pembelajaran menunjukkan bahwa model RPP yang dikembangkan dipandang layak digunakan sebagai sumber belajar. RPP dipandang sebagai aspek kunci dari mengajar pelajaran sukses (Richards \& Renandya, 2002, p. 27). RPP pembelajaran menulis teks eksposisi dikembangkan berdasarkan langkah-langkah pembelajaran berbasis masalah. Adapun kompoenen RPP yang dikembangkan berdasarkan Priyatni (2014, pp. 164-165) antara lain: (a) identitas sekolah; (b) identitas mata pelajaran; (c) kelas/semester; (d) materi pokok; (e) alokasi waktu; (f) kompetensi inti; (g) kompetensi dasar dan indikator pencapaian kompetensi; (h) tujuan pembelajaran; (i) materi pembelajaran, memuat fakta, konsep, prinsip, dan prosedur yang relevan; (j) metode pembelajaran; (k) media pembelajaran; (l) sumber belajar; (m) langkah-langkah pembelajaran dilakukan melalui tahapan pendahuluan, inti, dan penutup. (n) penilaian hasil belajar; dan (o) kebahasaan.

Tabel 4. Skor Hasil Validasi Perangkat Pembelajaran

\begin{tabular}{lclcccc}
\hline \multicolumn{1}{r}{ Validator } & Silabus & \multicolumn{1}{c}{ RPP } & BAS & IEP $($ S $)$ & IEP $(\mathrm{P})$ & IEP $(\mathrm{K})$ \\
\hline \multicolumn{1}{c}{1} & 69 & 183 & 185 & 120 & 128 & 128 \\
\multicolumn{1}{c}{2} & 64 & 168 & 169 & 125 & 117 & 118 \\
Total & 133 & 351 & 354 & 245 & 245 & 246 \\
Rerata skor total & 66,5 & 175,5 & 177 & 122,5 & 122,5 & 123 \\
Rerata Skor & 4,16 & 4,18 & 4,02 & 4,08 & 4,08 & 4,10 \\
Kategori & Valid & Valid & Valid & Valid & Valid & Valid \\
\hline
\end{tabular}

Keterangan:

IEP (S): instrumen evaluasi aspek sikap.

IEP (P): instrumen evalusi aspek pengetahuan.

$\operatorname{IEP}(\mathrm{K})$ : instrumen evaluasi aspek keterampilan. 
Kelayakan skor penilaian buku ajar siswa (BAS) 354 atau 4,02 dengan kategori "valid". Hasil penilaian yang diberikan oleh ahli materi dan pembelajaran menunjukkan bahwa model buku ajar siswa yang dikembangkan dipandang dari segi kelayakan dapat digunakan oleh siswa sebagai sumber belajar dan dapat dipertanggungjawabkan. Hal ini dikemukakan Poerwati \& Amri (2013, p. 207) bahwa materi pembelajaran perlu memperhatikan hal-hal berikut: (1) sahih (valid), (2) tingkat kepentingan, (3) kebermaknaan, (4) layak dipelajari, dan (5) menarik minat. Produk buku ajar siswa (BAS) sangat membantu siswa dalam memahami materi yang disajikan. Hal senada dikemukakan oleh Tomlinson (2011) bahwa prinsip dasar keberadaan buku ajar adalah (1) materi pembelajaran memberikan pengaruh yang kuat kepada siswa, dan (2) materi pembelajaran membantu siswa merasa mudah untuk belajar.

Isi pembelajaran menulis teks eksposisi yang dikembangkan dalam buku ajar siswa mencakup penyajian buku menggunakan pendekatan PBM, uraian teori, contoh teks, materi latihan, dan materi penugasan, Hal ini sesuai dengan pendapat Prastowo (2012, pp. 174-175) bahwa buku teks pelajaran harus memenuhi standarstandar. Standar penilaian dirumuskan dengan melihat tiga aspek utama, yaitu materi, penyajian, dan bahasa atau keterbacaan.

Produk bahan ajar yang dikembangkan ini juga memuat berbagai contoh teks yang dikaji siswa. Contoh teks ini disajikan sebagai bahan kegiatan membaca dan menulis siswa. Kegiatan penugasan berupa perintah agar siswa melakukan kegiatan dalam rangka memeroleh pengalaman untuk melakukan kegiatan berbahasa. Aspek penyajian materi pelajaran yang dikembangkan dalam bahan ajar mencakup adanya kompetensi dasar, kejelasan tujuan pembelajaran, peta kompetensi, penahapan pembelajaran, kemudahan bahan untuk dipahami, dan keaktifan siswa.

Produk buku pembelajaran menulis teks eksposisi yang dikembangkan berdasarkan pendekatan PBM meliputi: aktivitas pembelajaran orientasi masalah, pengorganisasian untuk belajar, penyelidikan individual atau kelompok, penyajian hasil karya, dan refleksi dan evaluasi pemecahan masalah. Tahapan penyajian materi pembelajaran menulis teks eksposisi ini sesuai dengan pendapat Arends (2012, p. 411).

Kelayakan skor instrumen evaluasi pembelajaran (IEP) aspek sikap 245 atau 4,08 dengan kategori "valid", skor total aspek pengetahuan 245 atau 4,08 dengan kategori "valid", dan aspek keterampilan 246 atau 4,10 dengan kategori "valid". Oleh karena itu, jika analisis perangkat berdasarkan setiap aspek penilaian memenuhi kategori minimal "baik". Hasil penilaian yang diberikan oleh ahli materi dan pembelajaran menunjukkan bahwa instrumen evaluasi pembelajaran (IEP) yang dikembangkan dipandang dari segi kelayakan dapat digunakan oleh siswa sebagai sumber belajar dan dapat dipertanggungjawabkan. Pelaksanaan penilaian yang baik haruslah dilakukan secara terencana dengan baik pula yang melibatkan berbagai komponen terkait (Nurgiyantoro, 2013, p. 19).

Oleh karena itu, sesuai dengan kualitas produk yang telah ditetapkan dalam bab III bahwa produk yang dikembangkan dianggap layak jika aspek-aspek yang dinilai pada perangkat pembelajaran mencapai kategori minimal "baik". Dengan demikian, model perangkat pembelajaran yaitu: silabus, RPP, BAS, dan IEP yang dikembangkan dalam penelitian ini layak digunakan sebagai salah satu sumber belajar. Hal ini sesuai dengan dengan hasil penelitian yang dilakukan Syamsi (2012) yang menyatakan model perangkat pembelajaran yaitu silabus, RPP, buku ajar, instrumen evaluasi, dan panduan pembelajaran menulis layak sebagai salah satu alternatif dalam upaya meningkatkan kualitas pembelajaran di sekolah.

Selain memberikan penilaian, ada sejumlah koreksi dan saran dari validator yang menjadi dasar untuk melakukan revisi terhadap perangkat pembelajaran yang dikembangkan. Koreksi dan saran dari ahli materi dan pembelajaran adalah sebagai berikut: Silabus: (1) setiap halaman baru dalam penulisan silabus diberi identitas judul di setiap kepala tabel. RPP: (1) lengkapi instrumen penilaian dengan menuliskan soal di RPP; (2) buku referensi yang menjadi rujukan untuk aspek sumber belajar di dalam RPP ditulis lengkap. Buku Ajar Siswa (BAS): (1) fase aktivitas pembelajaran tidak dimasukkan ke dalam daftar isi; (2) apa fungsi gambar koran jika tidak bisa dibaca; (3) penomoran angka romawi (I, II, III) diganti dengan angka arab (1,2,3); dan (4) gambar sampul kurang fokus. Instrumen Evaluasi Pembelajaran (IEP): (1) perbaiki KD aspek keterampilan menangkap makna teks eksposisi baik; (2) indikator soal nomor 8 diubah dengan menyebutkan jenis teks lebih dahulu; (3) soal aspek keterampilan disusun dengan nomor urut; (4) soal aspek keterampilan setiap teks diberikan penjelasan untuk soal nomor apa saja; dan (5) usahakan panjang-pendek teks untuk soal sama (jumlah kata). 


\section{Kepraktisan Produk Uji Coba Terbatas dan Uji Coba Luas}

Kepraktisan perangkat pembelajaran dalam penelitian ini dilihat berdasarkan penilaian sebagai berikut: (1) lembar keterlaksanaan pembelajaran, (2) lembar penilaian guru, dan (3) lembar penilaian siswa.

Penilaian keterlaksanaan dilakukan hasil pengamatan observer yang telah diisi dan dijumlahkan menjadi skor aktual. Data diperoleh dari aktivitas uji coba terbatas dan uji coba luas. Perangkat dikatakan praktis apabila pembelajaran dapat terlaksana dengan baik. Skor keterlaksanaan pembelajaran tersaji pada Tabel 5 .

Tabel 5. Skor Keterlaksanaan Pembelajaran

\begin{tabular}{llcc}
\hline No. & \multicolumn{1}{c}{ Uji Coba } & $\begin{array}{c}\text { Rerata Skor } \\
\text { Total }\end{array}$ & Kategori \\
\hline 1. & $\begin{array}{l}\text { Terbatas } \\
\text { Persentase }\end{array}$ & 74 & Baik \\
& Keterlaksanaan & 82,21 & \\
Luas & 79,75 & Sangat \\
2. & Persentase & 88,54 & Baik \\
& Keterlaksanaan & 8 & \\
\hline
\end{tabular}

Berdasarkan tabel 6 menunjukkan bahwa produk perangkat pembelajaran berdasarkan pendekatan PBM dapat memenuhi kategori praktis baik uji coba terbatas maupun uji coba luas. Hal ini dapat dilihat hasil pengamatan pembelajaran yang dilakukan memperoleh nilai minimal kategori baik.

Temuan yang diperoleh dari hasil pengamatan menunjukkan kegiatan siswa dalam aktivitas pembelajaran berkelompok ditemukan siswa aktif dalam menyampaikan ide sesuai dengan orientasi masalah yang diberikan. Hal ini sesuai dengan yang dikemukakan oleh Williford (2015, p. 23) bahwa pendekatan PBM dapat memberikan kesempatan kepada guru dalam mengintegrasikan manfaat-manfaat kerja kelompok dalam meningkatkan komitmen siswa untuk belajar.

Selanjutnya, penilaian kepraktisan berdasarkan penilaian guru. Kegiatan yang dilakukan seluruh skor pada lembar penilaian instrumen yang telah diisi oleh guru dijumlahkan menjadi skor aktual kepraktisan dari guru. Perangkat yang dikembangkan dikatakan telah memenuhi kriteria kepraktisan yaitu jika telah memenuhi kriteria kepraktisan yang dicapai mudah dilaksanakan, yakni; (1) silabus, (2) RPP, (3) buku ajar siswa (BAS), dan (4) instrumen evaluasi pembelajaran (IEP). Skor kepraktisan perangkat pembelajaran menurut penilaian guru tersaji pada Tabel 6 .
Tabel 6. Skor Kepraktisan Penilaian Guru

\begin{tabular}{|c|c|c|c|c|c|}
\hline No. & $\begin{array}{c}\text { Uji } \\
\text { Coba }\end{array}$ & $\begin{array}{c}\text { Jumlah } \\
\text { Skor } \\
\text { Total }\end{array}$ & $\begin{array}{c}\text { Rerata } \\
\text { Skor }\end{array}$ & $\begin{array}{l}\text { Persentase } \\
\text { Penilaian } \\
\text { guru }\end{array}$ & Kategori \\
\hline 1. & Terbatas & 103 & 4,29 & $85,8 \%$ & $\begin{array}{c}\text { Sangat } \\
\text { Baik }\end{array}$ \\
\hline 2. & Luas & 105 & 4,33 & $86,67 \%$ & $\begin{array}{c}\text { Sangat } \\
\text { Baik }\end{array}$ \\
\hline
\end{tabular}

Selain dari hasil penilaian guru, dalam penelitian ini mencermati hasil penilaian siswa. Perangkat pembelajaran yang dikembangkan memiliki kriteria praktis jika $80 \%$ siswa memberikan penilaian yang menunjukkan respon siswa berada pada kategori minimal baik. Hasil penilaian siswa terhadap perangkat pembelajaran yang dikembangkan disajikan pada Tabel 7.

Tabel 7. Skor Penilaian Siswa

\begin{tabular}{|c|c|c|c|}
\hline \multirow{2}{*}{ No. } & \multirow{2}{*}{ Hasil Penilaian } & \multicolumn{2}{|c|}{ Uji Coba } \\
\hline & & Terbatas & Luas \\
\hline 1. & Jumlah Skor Total & 420 & 904 \\
\hline 2. & Rerata Skor & 4,20 & 4,52 \\
\hline 3. & $\begin{array}{l}\text { Persentase } \\
\text { Penilaian siswa }\end{array}$ & $84 \%$ & $90,40 \%$ \\
\hline 4. & Kategori & Baik & Sangat Baik \\
\hline
\end{tabular}

Berdasarkan Tabel 7, menunjukkan bahwa persentase penilaian siswa terhadap perangkat pembelajaran yang dikembangkan pada kategori minimal baik melebihi $80 \%$ baik uji coba terbatas maupun uji coba luas. Oleh karena itu, perangkat pembelajaran menulis teks eksposisi berdasarkan pendekatan PBM yang dihasilkan sudah mencapai kriteria praktis.

\section{Keefektifan Produk Uji Coba Terbatas dan Uji Coba Luas}

Pada tahap uji coba terbatas dan uji coba luas menguji keefektifan perangkat pembelajaran menulis teks eksposisi berdasarkan pendekatan pembelajaran berbasis masalah bagi siswa SMP. Keefektifan ditinjau dari peningkatan dan ketuntasan hasil belajar siswa. Keefektifan ditinjau dari instrumen evaluasi pembelajaran (IEP) aspek pengetahuan dari 10 siswa yang dijadikan sampel memeroleh rerata nilai 3,13 dengan rincian tuntas 9 siswa dengan persentase $90 \%$, sedangkan yang tidak tuntas 1 orang dengan persentase $10 \%$ mencapai kriteria ketuntasan minimal, yaitu $<2,67$. Adapun peningkatan (gain) hasil belajar 0,67 dengan kategori $g$ - sedang. Nilai siswa untuk aspek keterampilan memeroleh rerata nilai 3,32 $(\mathrm{B}+)$ dari 10 siswa, seluruh siswa dinyatakan tuntas. Sementara IEP aspek sikap siswa memeroleh rerata skor 4,07 dan rerata nilai siswa 3,26 kategori baik. Dilihat dari ketuntasan 
belajar untuk IEP aspek sikap 100\% siswa dinyatakan tuntas.

Pada uji coba luas semua aspek untuk mengukur keefektifan memenuhi kriteria yang telah ditetapkan. Keefektifan juga tercapai, ditinjau dari $100 \%$ dari 20 siswa mencapai kriteria ketuntasan minimal $<2,67$ dengan rerata nilai 3,35. Peningkatan (gain) hasil belajar sebelum pembelajaran dimulai dan sesudah adalah 40,11 atau 0,66 dengan kategori $g$ - sedang. Nilai siswa untuk IEP aspek keterampilan memeroleh rerata nilai 3,28 (B+) dari 20 siswa, 20 siswa dinyatakan tuntas, dengan persentase ketuntasan $100 \%$. Sementara IEP aspek sikap siswa memeroleh rerata skor 4,07 dan rerata nilai siswa 3,35 kategori sangat baik, Ditinjau dari ketuntasan belajar untuk IEP aspek sikap 100\% siswa dinyatakan tuntas.

Berdasarkan uji coba terbatas dan uji coba luas produk perangkat menulis teks eksposisi berdasarkan pendekatan PBM ditinjau dari segi keefektifannya dikategorikan efektif dengan temuan-temuan hasil sebagai berikut. Pertama, aspek sikap, keterampilan, dan pengetahuan siswa dalam pembelajaran dengan berdasarkan pendekatan PBM ditemukan sangat membanggakan. Hal ini sesuai dengan apa yang disampaikan oleh Khatiban dan Sangestani (2014, p. 698) bahwa PBM dapat meningkatkan kompetensi, sikap, dan kinerja para siswa di sekolah. Kedua, produk yang dikembangkan ditemukan dapat menumbuhkan semangat kerjasama yang baik dalam menyelesaikan permasalahan yang dihadapi dan munculnya semangat membantu teman yang mengalami kesulitan dalam memahami materi pembelajaran.

Penelitian pengembangan ini telah dilaksanakan dengan optimal agar mencapai hasil yang baik. Namun, fakta di lapangan masih banyak terdapat kekurangan-kekurangan yang disebabkan oleh beberapa keterbatasan. Keterbatasan tersebut adalah sebagai berikut. Pertama, perangkat pembelajaran yang akan dikembangkan hanya terbatas pada materi teks eksposisi. Kedua, penelitian pengembangan ini dilakukan pada tahap uji coba uji coba luas dan tidak sampai pada tahap mendesiminasikan perangkat pembelajaran yang telah disusun. Ketiga, penelitian pengembangan ini dalam kegiatan uji coba terbatas dengan jumlah peserta uji coba 10 siswa, sedangkan berdasarkan hasil uji coba terbatas jumlah uji coba luas yang seharusnya 30 siswa yang diterapkan 20 orang siswa. Hal ini dilakukan dengan pertimbangan efektivitas dalam memantau proses pembelajaran yang dilakukan dalam penelitian uji coba luas.

\section{SIMPULAN}

Berdasarkan hasil pembahasan, maka dapat diambil simpulan sebagai berikut. Pertama, model perangkat pembelajaran yang dikembangkan dalam penelitian pengembangan perangkat menulis teks eksposisi berdasarkan pendekatan PBM bagi siswa SMP, yakni (1) silabus, (2) RPP, (3) buku ajar siswa, dan (4) instrumen evaluasi pembelajaran. Kedua, perangkat pembelajaran menulis teks eksposisi berdasarkan pendekatan PBM layak untuk digunakan berdasarkan hasil validasi ahli materi dan pembelajaran. Ketiga, Perangkat pembelajaran menulis teks eksposisi berdasarkan pendekatan PBM dapat dikatakan "praktis" untuk digunakan. Hal itu dapat dilihat dari (1) observasi terhadap keterlaksanaan pembelajaran baik uji coba terbatas maupun luas mencapai kategori "sangat baik"; (2) angket penilaian guru dinyatakan "sangat baik" pada uji coba terbatas dan luas; (3) respon siswa pada uji coba terbatas maupun uji coba luas $100 \%$ siswa menilai pembelajaran dengan kategori minimal "baik". Keempat, perangkat pembelajaran menulis teks eksposisi berdasarkan pendekatan PBM dapat dikatakan "efektif" untuk digunakan. Hal ini dapat dilihat dari tiga aspek, yaitu: (1) IEP aspek sikap siswa pada uji coba terbatas dan uji coba luas siswa dinyatakan tuntas serta dapat memberdayakan sikap siswa. (2) Aspek pengetahuan ketuntasan belajar siswa pada uji coba terbatas memeroleh rerata nilai 3,13 dengan ketuntasan individual 9 siswa dinyatakan tuntas dari 10 siswa, sedangkan ditinjau secara klasikal dengan ketuntasan 90\% dengan peningkatan 0,6 dengan kategori g-sedang. Adapun hasil uji coba luas siswa memeroleh rerata nilai 3,16 dengan ketuntasan individual 20 siswa dinyatakan tuntas dari 20 siswa dan dilihat ketuntasan klasikal $100 \%$ siswa dinyatakan tuntas. Sementara dilihat dari peningkatan 0,66 kategori g-sedang. (3) IEP aspek keterampilan pada uji coba terbatas dan uji coba luas siswa dinyatakan tuntas.

\section{DAFTAR PUSTAKA}

Arends, R. I. (2012). Learning to teach. (Ninth.ed). New York: McGraw-Hill Companies, Inc.

Daryanto, D., \& Dwicahyono, A. (2014). Pengembangan perangkat pembelajaran. Yogyakarta: Gava Media. 
Cipto Cipto

Gall, M. D., Gall, J. P., \& Borg, W. R. (2007). Educational research: An introduction. Boston: Pearson/Allyn \& Bacon.

Kementerian Pendidikan dan Kebudayaan Republik Indonesia. (2014). Materi pelatihan guru implementasi kurikulum 2013 tahun 2014 mata pelajaran bahasa Indonesia. Jakarta: Badan Pengembangan Sumber Daya Manusia Pendidikan dan Penjaminan Mutu Pendidikan.

Khatiban, M., \& Sangestani, G. (2014). The effects of using problem-based learning in the clinical nursing education on the students' outcomes in Iran: A quasiexperimental study. Nurse education in practice, 14(6), 698-703.

Mahsun. (2014). Teks dalam pembelajaran bahasa Indonesia Kurikulum 2013. PT RajaGrafindo Persada.

Nely, A. (2014). Pengaruh model gambar dan gambar terhadap kemampuan menulis teks eksposisi oleh siswa kelas X SMA Negeri 1 Gebang tahun pembelajaran 2013/2014. Basastra, 3(1).

Nurgiyantoro, B. (2013). Penilaian pembelajaran bahasa berbasis kompetensi. Yogyakarta: BPFE-Yogyakarta.

Prabhu, N. S. (1987). Second language pedagogy. Oxford: Oxford University Press.

Prastowo, A. (2012). Panduan kreatif membuat bahan ajar inovatif. Yogyakarta: Diva Press.

Priyatni, E. T. (2014). Desain pembelajaran bahasa indonesia dalam Kurikulum 2013. Jakarta: PT Bumi Aksara.
Poerwati, L. E., \& Amri, S. (2013). Panduan memahami Kurikulum 2013. Jakarta: PT Prestasi Pustakaraya.

Richards, J. C., \& Renandya, W. A. (Eds.). (2002). Methodology in language teaching: An anthology of current practice. Cambridge university press.

Slavin, R. E (2011) Psikologi pendidikan: teori dan praktik edisi kesembilan, jilid 2. (Terjemahan Marianto Samosir). Jakarta: PT Indeks.

Sukardjo. (2014). Evaluasi pembelajaran IPA (buku pegangan kuliah). Yogyakarta: Program Studi Pendidikan Sains PPS UNY.

Syamsi, K. (2012). Model perangkat pembelajaran menulis berdasarkan pendekatan proses genre bagi siswa SMP. LITERA,

$11(2)$ doi:https://doi.org/10.21831/ltr.v11i2.1070

Tarigan, H.G. (2013). Menulis sebagai suatu keterampilan berbahasa. Bandung: Penerbit Angkasa Bandung.

Tomlinson, B. (Ed.). (2011). Materials development in language teaching. Cambridge University Press.

Ur, P. (2009). A cource in language teaching practice and theory. (Rev.ed). New York: Cambridge University Press.

Williford, B. (2015). Combining problem based learning and activism in a feminist classroom. Theory in Action, 8(1).

Wong, R.Y.L. (2002). Teaching text type in the Singapore primary classroom. Prentice Hall SprintPrint. 